\title{
Hydrogen pre-charging effects on the notch tensile properties and fracture behaviour of heat-affected zones of thermally aged welds between T24 and T92 creep-resistant steels
}

\author{
L. Falat ${ }^{*}$, L. Ciripová ${ }^{1}$, V. Homolová ${ }^{1}$, P. Futáś̃, P. Ševc ${ }^{1}$ \\ ${ }^{1}$ Institute of Materials Research, Slovak Academy of Sciences, Watsonova 47, 04001 Košice, Slovak Republic \\ ${ }^{2}$ Technical University of Košice, Faculty of Metallurgy, Institute of Metallurgy, Letná 9, 04200 Košice, Slovak Republic
}

Received 25 May 2016, received in revised form 1 August 2016, accepted 2 August 2016

\begin{abstract}
The effects of thermal exposure at $600^{\circ} \mathrm{C}$ and subsequent electrolytic hydrogen charging at ambient temperature were studied in terms of their influence on notch-tensile properties and fracture behaviour of individual heat-affected zones (HAZ) of Ni-based transition weldments between T24 and T92 creep-resistant steels. The experimental welded joints were prepared by gas tungsten arc welding using "Inconel-type" filler metal Nirod 600. Post-weld heat treatment (PWHT) was carried out at $720^{\circ} \mathrm{C}$ for $2 \mathrm{~h}$, followed by passive cooling within tempering furnace. Subsequent long-term ageing of two series of prepared T24/T92 dissimilar welds at $600{ }^{\circ} \mathrm{C}$ for 1000 and $5000 \mathrm{~h}$, respectively, led to gradual changes in both T24 and T92 HAZ microstructures, which were mainly related to their additional tempering accompanied by the coarsening of original precipitates as well as newly-formed secondary phases. The observed thermally-induced microstructural changes together with subsequently applied hydrogen charging effects resulted in complex variations in tensile properties and fracture behaviour of individual HAZ regions related to the pre-existing differences in their initial tempering grade due to the used PWHT procedure.
\end{abstract}

K e y w o r d s: creep-resistant steels, dissimilar welding, isothermal ageing, hydrogen embrittlement, mechanical properties, fracture mechanisms

\section{Introduction}

During long-term service in conditions of supercritically heated and pressurized steam, the welded joints of creep-resistant steels are known to undergo gradual degradation of their microstructures and mechanical properties [1, 2]. Moreover, individual regions of the welds, namely the base material (BM), weld metal (WM) and heat-affected zone (HAZ) degrade very specifically which consequently leads to their strongly differing properties $[3,4]$. The situation becomes even more complex in the case of dissimilar welds, i.e. the welded joints between chemically different steels which are very frequent in power engineering [5-8]. For instance, the dissimilar welds combined of lower and higher chromium ferritic steels, such as T24/T92 welded joints can be used in a number of steam generator circuits. The T24 steel is a low-alloy $2.25 \mathrm{Cr}-1 \mathrm{Mo}$ base tempered bainitic steel modified by small additions of $\mathrm{V}, \mathrm{Ti}, \mathrm{Nb}$, and $\mathrm{B}$. It has been designed for welding of steam evaporators in the form of membrane walls operating at $550-580^{\circ} \mathrm{C}$ [9-11]. Microstructural evolution and mechanical properties of T24 steels during long-term ageing and/or creep exposure have been widely studied by many authors [10-16]. These studies revealed precipitation of several secondary phases in T24 base materials and their welded joints such as $\mathrm{MX}, \mathrm{M}_{2} \mathrm{C}, \mathrm{M}_{6} \mathrm{C}, \mathrm{M}_{7} \mathrm{C}_{3}$, and $\mathrm{M}_{23} \mathrm{C}_{6}$, where $\mathrm{M}$ stands for various metallic elements, e.g. $\mathrm{V}, \mathrm{Nb}, \mathrm{Ti}$ in $\mathrm{MX}$; $\mathrm{Mo}$ in $\mathrm{M}_{2} \mathrm{C}$ and $\mathrm{M}_{6} \mathrm{C}$; and $\mathrm{Cr}$ in $\mathrm{M}_{7} \mathrm{C}_{3}$ and $\mathrm{M}_{23} \mathrm{C}_{6}$; $\mathrm{X}=\mathrm{C}, \mathrm{N})$. Moreover, it has been found out that long-term thermal exposure of T24 material leads to privileged carbide precipitation on grain boundaries, additional precipitation of $\mathrm{M}_{2} \mathrm{C}$ carbides, the enriching of MX carbonitrides with molybdenum and recovery processes of tempered bainitic microstructure

*Corresponding author: tel.: +421 55792 2447; fax: +421 55792 2408; e-mail address: lfalat@saske.sk 
Table 1. Chemical composition (wt.\%) of input materials used for fabrication of T24/T92 dissimilar weldments with Ni-based filler metal

\begin{tabular}{lcccccccccccccccc}
\hline & $\mathrm{C}$ & $\mathrm{N}$ & $\mathrm{Si}$ & $\mathrm{Mn}$ & $\mathrm{Cr}$ & $\mathrm{Mo}$ & $\mathrm{W}$ & $\mathrm{B}$ & $\mathrm{Ni}$ & $\mathrm{Al}$ & $\mathrm{V}$ & $\mathrm{Nb}$ & $\mathrm{Ti}$ & $\mathrm{Fe}$ \\
\hline T24 & 0.08 & 0.007 & 0.21 & 0.53 & 2.44 & 0.95 & - & 0.0042 & 0.18 & - & 0.36 & 0.002 & 0.053 & Balance \\
T92 & 0.11 & 0.056 & 0.38 & 0.49 & 9.08 & 0.31 & 1.57 & 0.0023 & 0.33 & 0.014 & 0.2 & 0.069 & - & Balance \\
Nirod 600 & 0.05 & - & 0.3 & 3.0 & 20.0 & - & - & - & Balance & - & - & 2.0 & - & 2.0 \\
\hline
\end{tabular}

[10]. The T92 steel is a $9 \mathrm{Cr}-0.5 \mathrm{Mo}-1.8 \mathrm{~W}$ base tempered martensitic steel with minor additions of $\mathrm{V}, \mathrm{Nb}$, and B, developed during the late 1990s through chemical composition modification of T91 (9Cr-1Mo base) steel, aimed for the improvement of high temperature creep strength $[17,18]$. Its main application area covers thick-section boiler components such as headers and main steam pipeline. Commonly, the T92 tubes are used for linking reheaters and superheaters up to $620^{\circ} \mathrm{C}$. The microstructure of $\mathrm{P} / \mathrm{T} 92$ base material is typically formed of tempered lath martensite with finely dispersed intragranular $\mathrm{MX}(\mathrm{M}=\mathrm{V}, \mathrm{Nb} ; \mathrm{X}=\mathrm{C}$, $\mathrm{N})$ carbonitrides and intergranular $\mathrm{M}_{23} \mathrm{C}_{6}(\mathrm{M}=\mathrm{Cr}$, Fe) carbides at grain, block, and lath boundaries [1721]. The most significant microstructural change in Grade 92 steels during their long-term ageing and/or creep exposure is the additional precipitation of intermetallic $\mathrm{Fe}_{2}$ (W, Mo) based Laves phase, typically in the vicinity of $\mathrm{M}_{23} \mathrm{C}_{6}$ carbides [19-24].

Generally, the long-term holding of dissimilar weldments at elevated temperatures induces microstructural changes in individual steels including carbon and nitrogen redistribution $[25,26]$. Therefore, Ni-based transition weldments, i.e. the dissimilar welds with Ni-based weld metal (Ni WM) serving as diffusion barrier are frequently used for suppression of interstitial elements migration [27].

Besides thermally induced degradation, the embrittlement of ferritic steels and their welded joints by the absorbed hydrogen, i.e. hydrogen embrittlement may be an issue in power generation plants $[28,29]$ during their cooling below $150^{\circ} \mathrm{C}$ after regular shut-downs or on the low-temperature side of the reactor or boiler equipment. Hydrogen dissolved in steels can lead to low threshold stress intensity for crack propagation at ambient temperature in tensile stress conditions resulting in so-called hydrogenassisted cracking (HAC). Several hydrogen acting mechanisms, e.g. hydrogen enhanced localized plasticity (HELP), hydrogen enhanced decohesion (HEDE), adsorption-induced dislocation emission (AIDE) and hydrogen enhanced strain induced vacancy formation (HESIV) have been proposed to interpret various forms of hydrogen embrittlement [30,31]. The role of hydrogen accumulation in steel matrix and/or at precipitate/matrix interfaces on the formation of cracks has also been widely discussed in the literature, e.g. [32-34]. However, due to the great complexity in mate- rials characteristics, testing, and environmental conditions, it is necessary to investigate each failure caused by hydrogen individually.

In our previous study [35] the effects of electrolytic hydrogen charging on the notch tensile properties and fracture behaviour of individual microstructural regions of dissimilar weld joints between several Cr-Mo-V ferritic and Cr-Ni-Mo austenitic steels in PWHT conditions were investigated. The additional influence of long-term ageing prior to hydrogen charging of dissimilar ferritic/austenitic weldments on their mechanical and fracture characteristics was studied in [36]. The present work investigates correlations between microstructure, mechanical properties and fracture behaviour of individual $\mathrm{HAZ}$ regions of T24/T92 transition weldment in conditions after PWHT and long-term ageing without or with subsequent hydrogen charging.

\section{Experimental procedure}

The T24 and T92 steels tubes of $38 \mathrm{~mm}$ in their outer diameter and $5.6 \mathrm{~mm}$ of their wall thickness were circumferentially welded by tungsten inert gas method using Ni-based filler metal Nirod 600. This "Inconel-type" alloy is commonly used for welding of dissimilar or difficult to weld steels. The chemical composition of individual input materials used for the production of experimental weldments under investigation is given in Table 1.

Produced dissimilar weldments were initially subjected to PWHT at $720^{\circ} \mathrm{C}$ for $2 \mathrm{~h}$ with subsequent passive cooling in tempering furnace. The first series of prepared T24/T92 Ni-based transition weldments was investigated in its PWHT state. Preliminary estimation of local mechanical properties of the studied weldment configuration was performed by its cross-weld Vickers hardness measurement at room temperature using a load of $98 \mathrm{~N}$. The next two series of the produced weldments were isothermally aged at $600{ }^{\circ} \mathrm{C}$ for 1000 and $5000 \mathrm{~h}$, respectively. Microstructure evolution and mechanical properties degradation depending on thermal exposure duration were determined by metallographic analysis and room-temperature tensile tests, respectively. Thermodynamic calculations were performed using the software Thermo-Calc [37] and thermodynamic database 


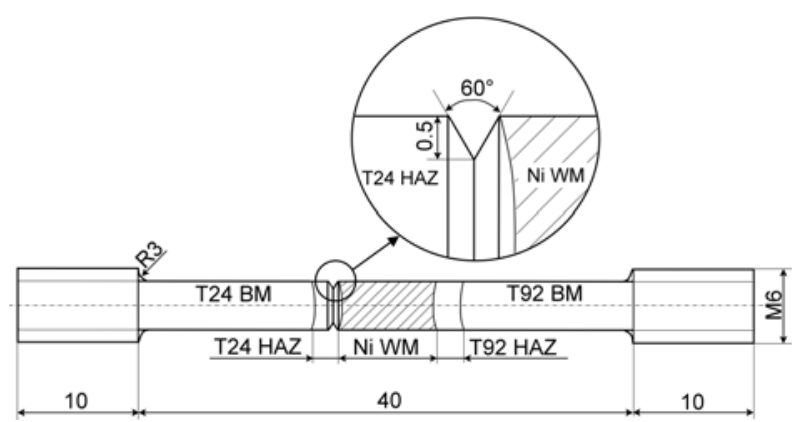

Fig. 1. Cylindrical specimen with circumferential V-notch in T24 HAZ used for tensile testing of investigated T24/T92 dissimilar weldments in different material states.

(Alternatively, the T92 HAZ region was V-notched.)

STEEL16 [38] to predict phase equilibria in long-term aged material states and to support the experimental findings. From the weldments of all heat-treated states (i.e. PWHT, $600^{\circ} \mathrm{C} / 1000 \mathrm{~h}, 600^{\circ} \mathrm{C} / 5000 \mathrm{~h}$ ), cylindrical tensile specimens ( $4 \mathrm{~mm}$ body diameter, $40 \mathrm{~mm}$ gauge length, and M6 head) were machined. The body surfaces of cross-weld tensile specimens were macroetched in a $3 \%$ Nital solution in order to distinguish between individual dissimilar materials of the weldments. Applying the mentioned etching solution, the T24 material became etched, whereas $\mathrm{Ni} W M$ and T92 materials remained un-etched. Next, the tensile specimens were circumferentially "V"-notched. The notch was alternately located within individual coarse-grained HAZ regions (over-heated zones) of produced cross-weld specimens, i.e. either in T24 HAZ or in T92 HAZ (see Fig. 1).

One portion of the notched tensile specimens in all heat-treated states was subjected to tensile testing in the condition without hydrogen charging. The remaining specimens were subjected to electrolytic hydrogen charging at ambient temperature prior to the tensile testing. The specimens were cathodically pre-charged with hydrogen for $24 \mathrm{~h}$ in a solution of $1 \mathrm{M} \mathrm{HCl}$ with $0.1 \mathrm{~N} \mathrm{~N}_{2} \mathrm{H}_{6} \mathrm{SO}_{4}$ at a current density of $200 \mathrm{~A} \mathrm{~m}^{-2}$. The used experimental technique was optimized by our previous experience [35] which indicated full saturation of tensile samples by hydrogen after $24 \mathrm{~h}$ of electrolytic charging. Immediately after the hydrogen charging, room temperature tensile tests were carried out at a strain rate of $2.1 \times 10^{-4} \mathrm{~s}^{-1}$ allowing the investigation of hydrogen effects for short-term loading conditions. From performed mechanical tests the values of notch tensile strength $\left(R m_{\mathrm{V}}\right)$ and reduction of area under the notch $\left(R A_{\mathrm{V}}\right)$ were evaluated as average values from three individual measurements for each material state. Microstructure and fracture analyses of broken tensile specimens were carried out using light microscopy (LM) and scanning electron microscopy (SEM) linked with energy dispersive X-ray (EDX) analysis.
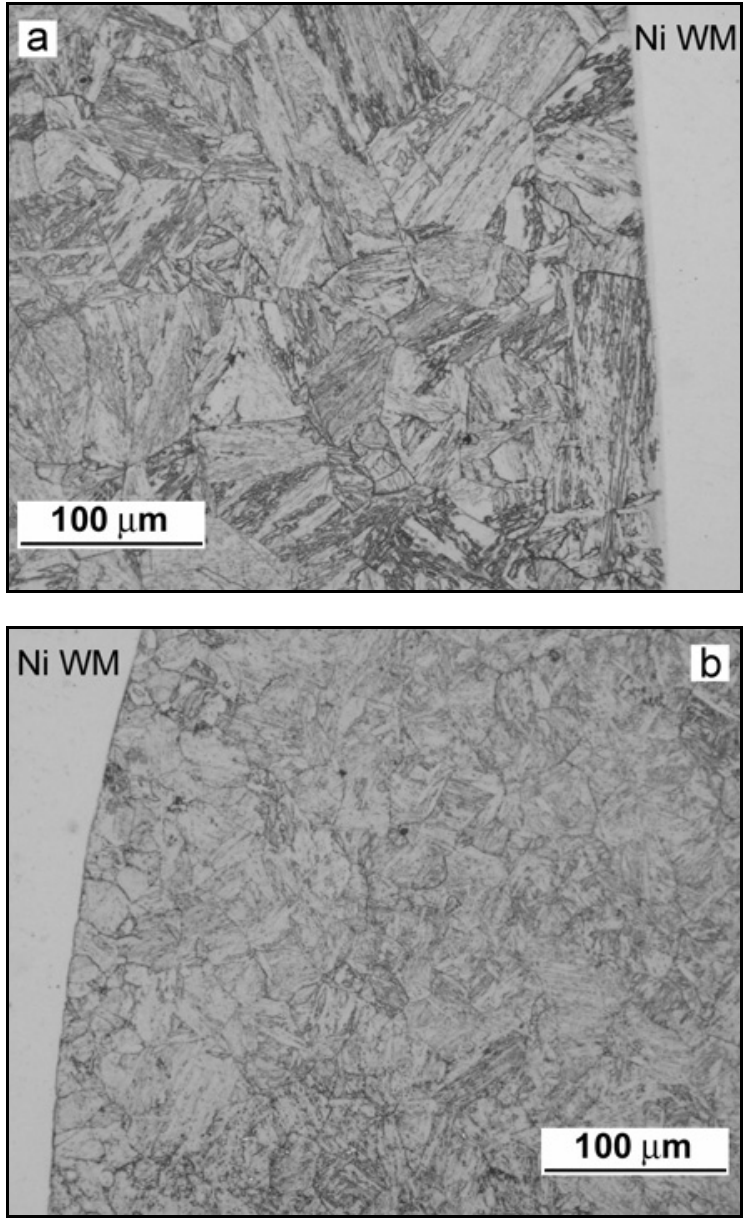

Fig. 2. Light-optical microstructures of individual HAZ regions of a T24/T92 weldment in its PWHT state: tempered bainitic T24 HAZ (a) and tempered martensitic T92 HAZ (b)

\section{Results and discussion}

\subsection{Microstructure in PWHT state}

General view on light-optical microstructures of T24 HAZ and T92 HAZ regions of studied dissimilar weldment in its initial PWHT state is documented in Fig. 2.

The main difference between the individual HAZ microstructures is obviously related to the size of prior austenitic grains in HAZ close to Ni WM. Moreover, Figs. 3 and 4 show the detailed SEM images of both the HAZ regions, indicating their additional differences in density and distribution of secondary phase precipitates. The T24 HAZ exhibits significantly higher grain size and lower density of precipitates (Figs. 2a and 3). In contrast, the T92 HAZ shows much finer microstructure due to the higher density of secondary phase particles, hindering the grain growth during the welding thermal cycle (Figs. 2b and 4). 

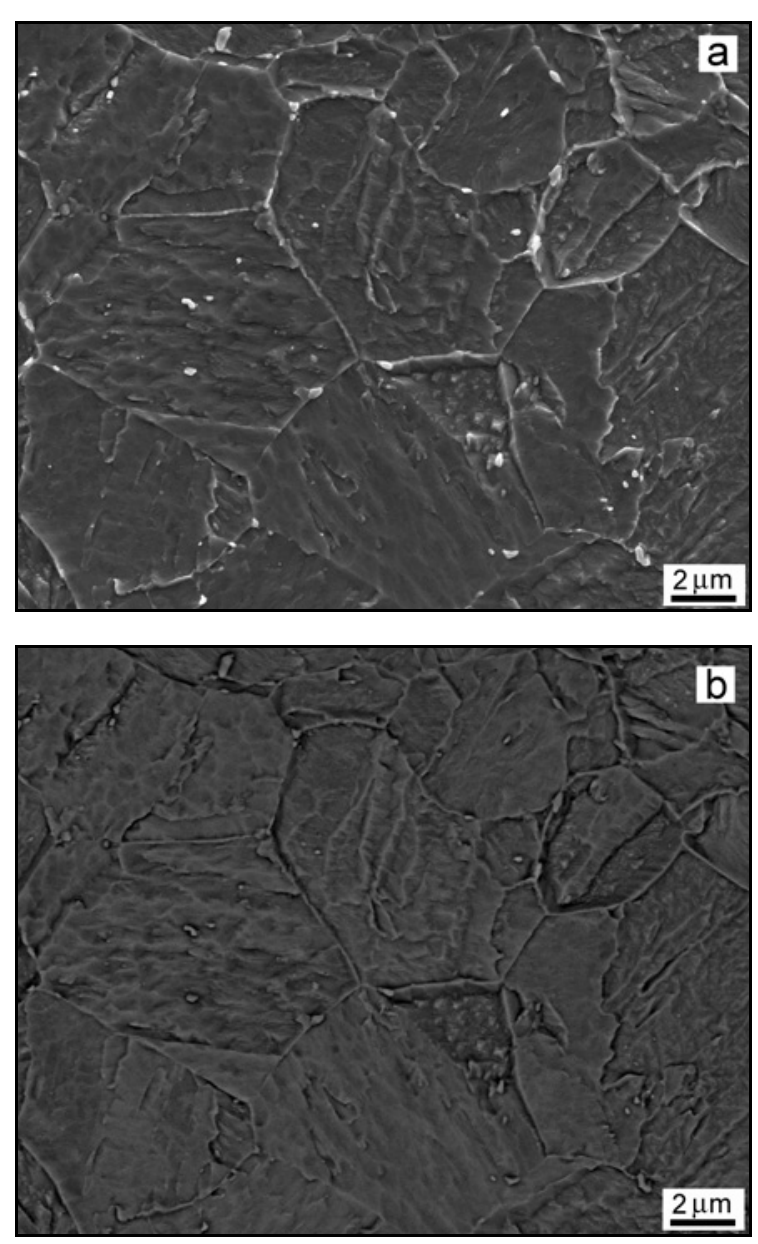

Fig. 3. SEM images of T24 HAZ of a T24/T92 weldment in PWHT state visualized in the mode of secondary electrons (a) and back-scattered electrons (b).

Detailed microstructural analysis of Nirod 600 weld metal was performed in our previous studies on T92/TP316H weldments $[39,40]$.

\subsection{Mechanical properties and microstructure evolution}

Preliminary determination of local mechanical properties of studied T24/T92 weldment in PWHT state was carried out by cross-weld hardness profile measurement (see Fig. 5).

The obtained hardness profile clearly indicated the over-heated T24 and T92 coarse-grained HAZ regions located next to Ni WM to be the most critical regions with respect to their highest hardness values within the whole weldment. The observed hardness peaks can be related to the highest level of transformation hardening in these regions due the maximal alloying effect in corresponding microstructures heated up to the highest peak temperatures during the welding thermal cycle [41]. Moreover, it has been shown in many
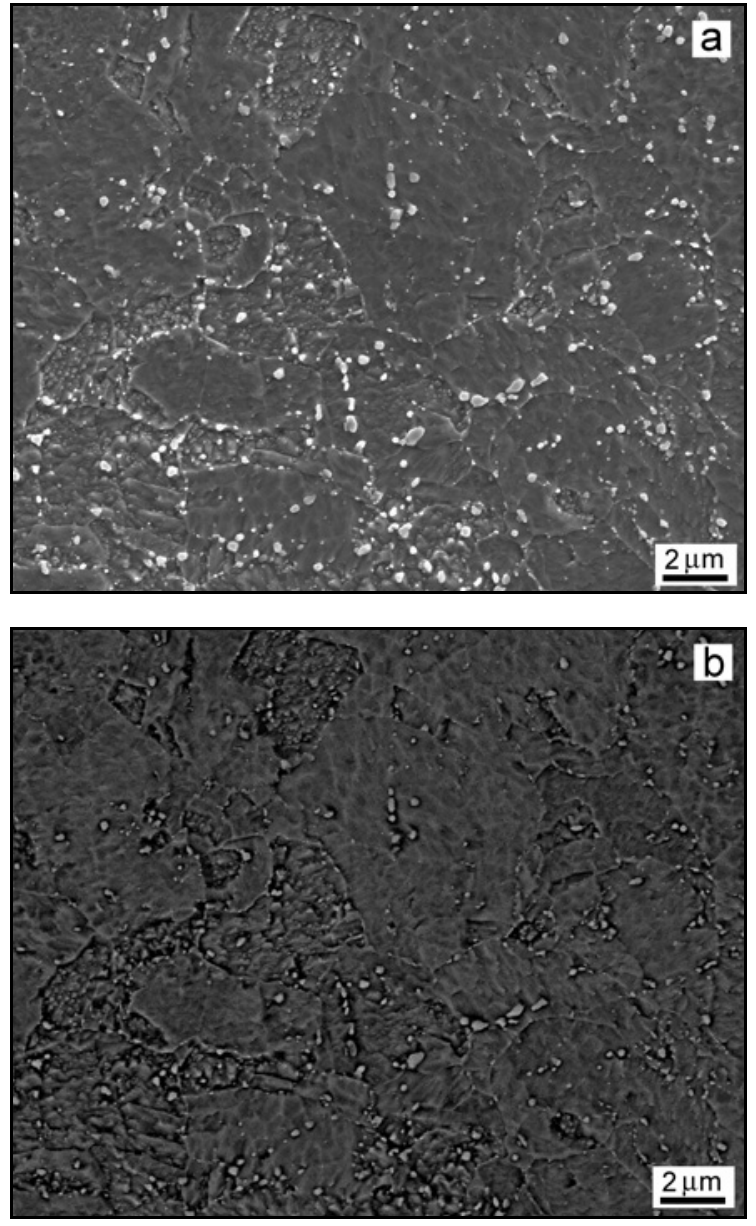

Fig. 4. SEM images of T92 HAZ of a T24/T92 weldment in PWHT state visualized in the mode of secondary electrons (a) and back-scattered electrons (b).

studies, e.g. $[40,42,43]$ that hardness peaks in the welds over-heated regions remain still present even after long-term thermal or creep expositions. Therefore, in the present investigation, all experimental work was focused on these critical HAZ regions. The results of room-temperature notch tensile tests of individual HAZ regions of T24/T92 weldments in different material states with regard to the heat treatment condition (PWHT, $600^{\circ} \mathrm{C} / 1000 \mathrm{~h}, 600^{\circ} \mathrm{C} / 5000 \mathrm{~h}$ ) and the application of hydrogen charging are graphically illustrated in Fig. 6.

From Fig. 6a it is visible that the values of notch tensile strength $\left(R m_{\mathrm{V}}\right)$ of both T24 HAZ and T92 HAZ regions in condition without hydrogen charging show noticeable initial increase after $1000 \mathrm{~h}$ of thermal exposure at $600^{\circ} \mathrm{C}$, followed by their gradual decrease with further increasing of ageing time up to $5000 \mathrm{~h}$. This result correlates well with findings of Mohyla and Foldyna [11] who observed the similar tendency of hardness values in over-heated coarse-grained HAZ of their homogeneous T24/T24 weldments subjected 


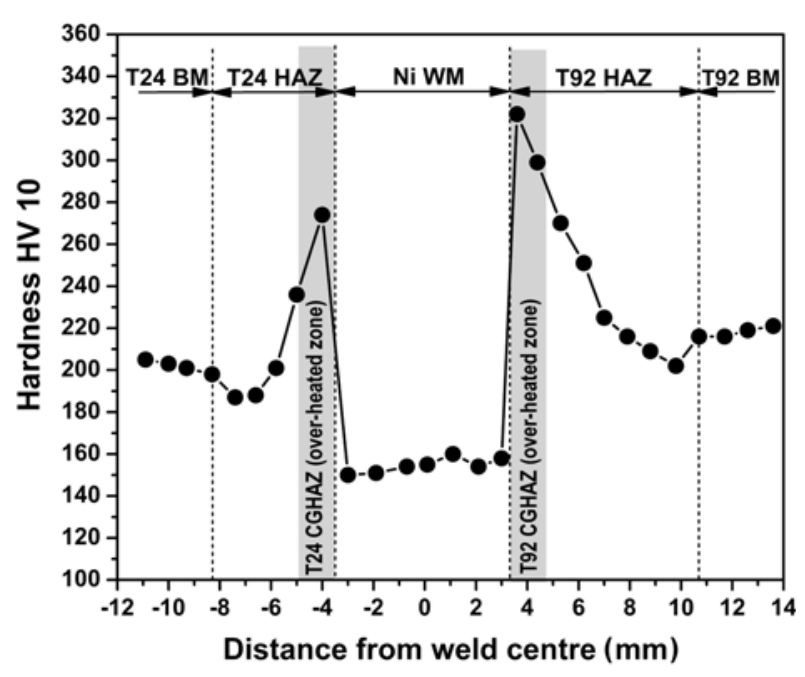

Fig. 5. Hardness profile of T24/T92 weldment in PWHT state depicting the most critical weld locations to be the over-heated zones, i.e. the coarse-grained T24 HAZ and T92 HAZ regions.
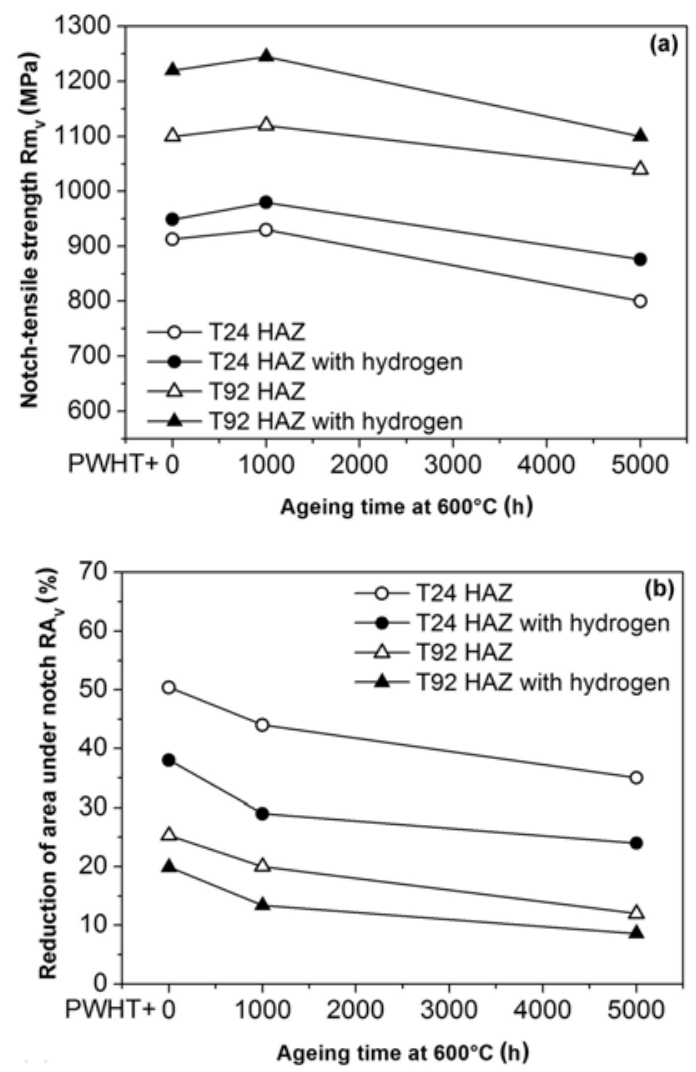

Fig. 6. Notch tensile properties of individual HAZ regions of T24/T92 weldments in different material states with respect to the heat treatment condition and hydrogen charging application: notch tensile strength (a) and reduction of area under the notch (b). to PWHT at $750^{\circ} \mathrm{C}$ for $2 \mathrm{~h}$ and subsequent long-term ageing at $550^{\circ} \mathrm{C}$. In accordance with literature data, e.g. $[10,11]$, the initial hardening and subsequent softening effects in T24 HAZ also observed in present study can mainly be related to the additional fine precipitation of $\mathrm{MX}$ and $\mathrm{M}_{2} \mathrm{C}$ strengthening precipitates, followed by the loss of hardening effects with increasing ageing time due to the coarsening of Cr-rich carbides on grain boundaries, additional formation of Mo-rich $\mathrm{M}_{6} \mathrm{C}$ carbides resulting in depletion of Mo atoms from solid solution and dissolution of a part of fine MX dispersions. On the other hand, a variation of $R m_{\mathrm{V}}$ values of T92 HAZ with annealing duration without application of hydrogen charging was rather insignificant (Fig. 6a). It can be assumed that the secondary hardening effects from additional fine precipitation of MX and Laves phase precipitates at the initial stage of their formation were compensated by the softening effects of recovery processes of the tempered martensitic microstructure of T92 HAZ together with coarsening of intergranular $\mathrm{M}_{23} \mathrm{C}_{6}$ carbides and Laves phase particles with increasing ageing duration. The coarsening of secondary phase precipitates during long-term ageing seems to be the general reason for decreasing plasticity [44], see $R A_{\mathrm{V}}$ values in Fig. 6b. Moreover, enhanced degradation processes in HAZ regions can be related to their welding-induced non-equilibrium thermal history resulting in high driving force for the observed microstructural changes [45]. SEM images in Figs. 7 and 8 demonstrate that after long-term ageing at $600{ }^{\circ} \mathrm{C}$ for $5000 \mathrm{~h}$, the microstructures of both T24 and T92 HAZ regions show obvious microstructural changes in terms of coarsening of intergranular chromium carbides $\left(\mathrm{M}_{7} \mathrm{C}_{3}\right.$ and/or $\left.\mathrm{M}_{23} \mathrm{C}_{6}\right)$ accompanied by the additional precipitation and coarsening of newly formed phases, namely the Mo-rich $\mathrm{M}_{6} \mathrm{C}$ carbides in T24 HAZ and $\mathrm{Fe}_{2}$ (W, Mo) based Laves phase in T92 HAZ, respectively.

These phases with high average atomic numbers, due to the presence of Mo in their crystal structure, were clearly distinguished from other carbide phases with relatively lower average atomic numbers using the back-scattered electrons mode in SEM (see Figs. $7 \mathrm{~b}$ and $8 \mathrm{~b}$ ). The presence of these secondary phases in T24 and T92 microstructures was also confirmed by thermodynamic calculations using ThermoCalc (Fig. 9).

Hydrogen charging of T24/T92 weldments in all heat-treated states (PWHT, $600{ }^{\circ} \mathrm{C} / 1000 \mathrm{~h}$, and $600{ }^{\circ} \mathrm{C} / 5000 \mathrm{~h}$ ) resulted in remarkable hardening effects on the notch tensile strength and significant detrimental effects on the plasticity of both studied HAZ regions (see Fig. 6). The observed strengthening effects can reasonably be correlated with interactions between absorbed hydrogen and free dislocations and/or precipitate/matrix interfaces in tempered bainitic T24 HAZ and tempered martensitic 

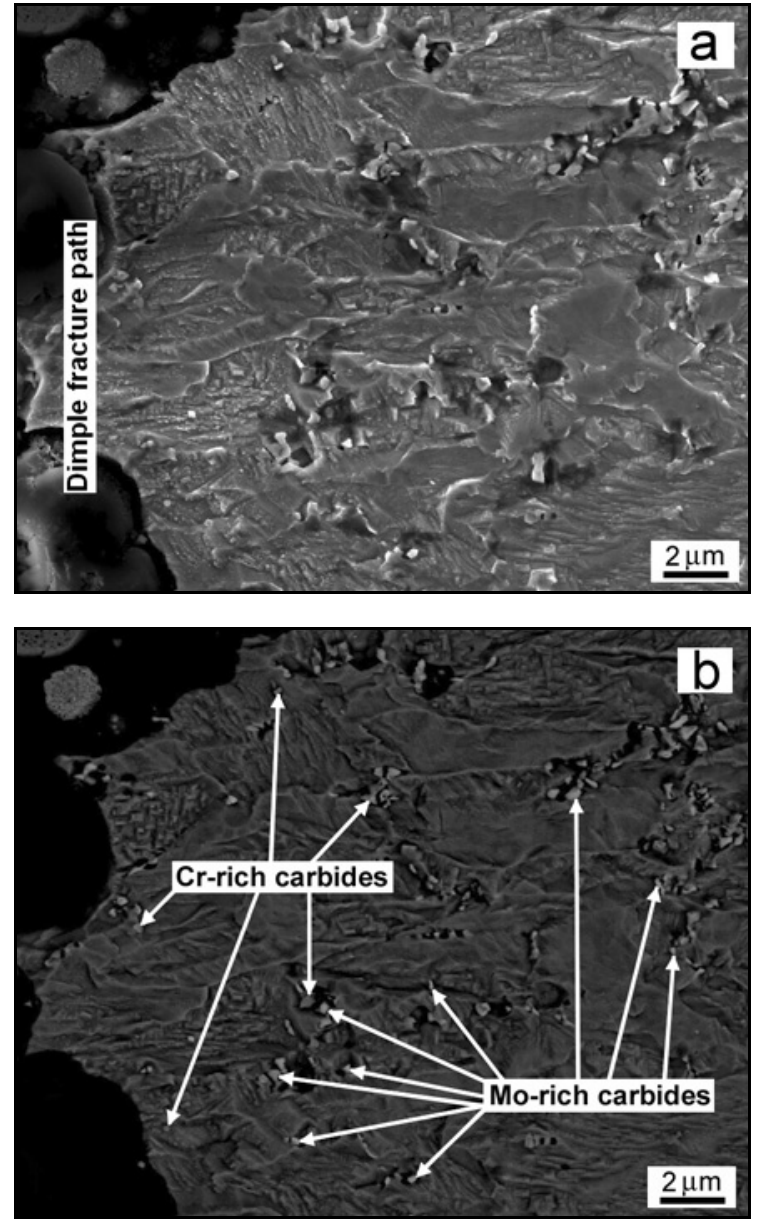

Fig. 7. SEM images of sub-fracture T24 HAZ microstructure after ageing at $600{ }^{\circ} \mathrm{C}$ for $5000 \mathrm{~h}$ and room-temperature tensile test without hydrogen pre-charging, visualized in the mode of secondary electrons (a) and back-scattered electrons (b).

T92 HAZ microstructures. It is well-known that pinning of dislocations by both absorbed hydrogen and secondary phase precipitates may result in hardening effects in steels and other alloys [46]. On the other hand, deleterious effects of hydrogen on $R A_{\mathrm{V}}$ values were clearly observed in both T24 HAZ and T92 HAZ regions in all heat-treated states of the studied weldment (see Fig. 6b). The origin of plasticity deterioration in the heat-treated states without application of hydrogen charging is generally known to be related to the thermal degradation of the microstructure. However, in the case of combined effects of thermal and hydrogen embrittlement, the situation is much more complex. There are plenty of different microstructural sites in steels such as grain boundaries, free dislocations, precipitates and inclusions which may interact with absorbed hydrogen and thus make effects on the resulting tensile properties and fracture behaviour. Figure $6 \mathrm{~b}$ indicates that the
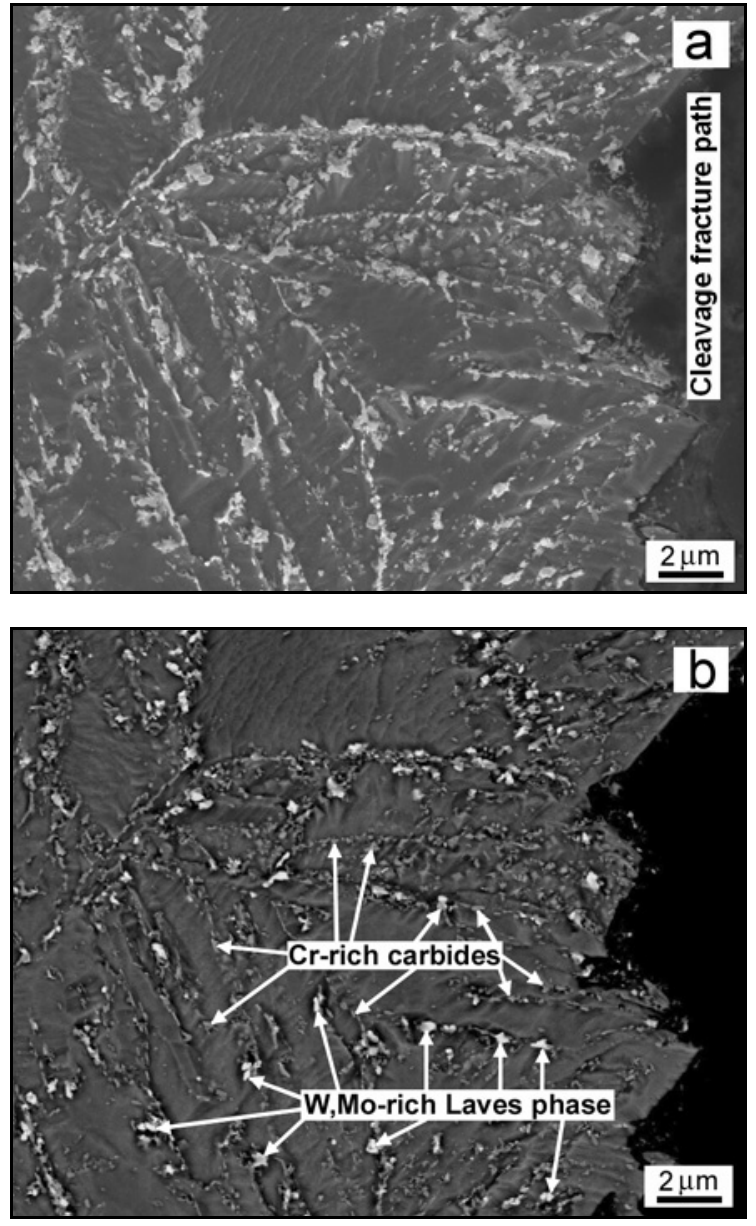

Fig. 8. SEM images of sub-fracture T92 HAZ microstructure after ageing at $600^{\circ} \mathrm{C}$ for $5000 \mathrm{~h}$ and room-temperature tensile test without hydrogen pre-charging, visualized in the mode of secondary electrons (a) and back-scattered electrons (b).

effect of additional carbide precipitation and/or coarsening during long-term thermal exposition may even have a slight positive effect on the resulting plastic properties through a certain suppression of hydrogen embrittlement by the mechanism of hydrogen trapping at the carbide/matrix interfaces, described also in many other studies [47-50]. These irreversible hydrogen traps can bind up free atomic hydrogen within the crystal lattice. The occurrence of this phenomenon in the present investigation can be supported by the observation that the relative difference in $R A_{\mathrm{V}}$ values between the hydrogen free and hydrogen charged specimens decreases gradually with increasing ageing time (Fig. 6b). However, besides the increase of irreversible hydrogen traps in the form of additional precipitation during long-term annealing, the decrease of reversible hydrogen traps such as free dislocations leading to partial softening effects in tempered T24 and T92 HAZ microstructures could also contribute to the observed 

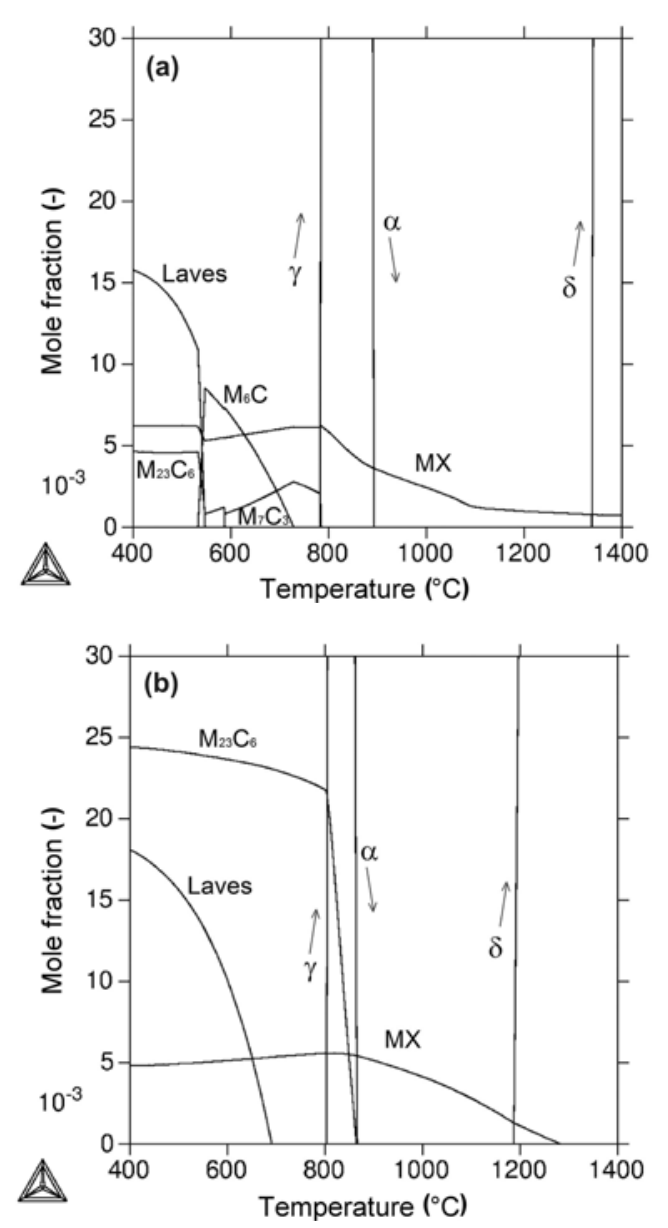

Fig. 9. Calculated mole fractions of stable phases in dependence of temperature for T24 steel (a) and T92 steel (b).

decreasing level of their total embrittlement (Fig. 6b). Thus it seems that the influence of hydrogen charging on the plasticity with increasing duration of thermal exposure decreases and the dominance of thermal embrittlement increases.

\subsection{Fracture behaviour}

SEM fractographs of fresh fracture surfaces of individual HAZ regions of studied weldments in different material states with respect to the heat treatment condition and application of hydrogen charging are visualized in Figs. 10-12.

Figure 10 shows fracture surfaces of T24 HAZ and T92 HAZ regions in initial PWHT state without hydrogen charging. Both fracture surfaces exhibit majority of ductile dimples with different sizes and morphologies.

The region of T92 HAZ also shows some minor portion of transgranular quasi-cleavage. After the ageing at $600{ }^{\circ} \mathrm{C}$ for $5000 \mathrm{~h}$, the fracture surface of $\mathrm{T} 24$ HAZ still exhibits ductile dimples but also the in-
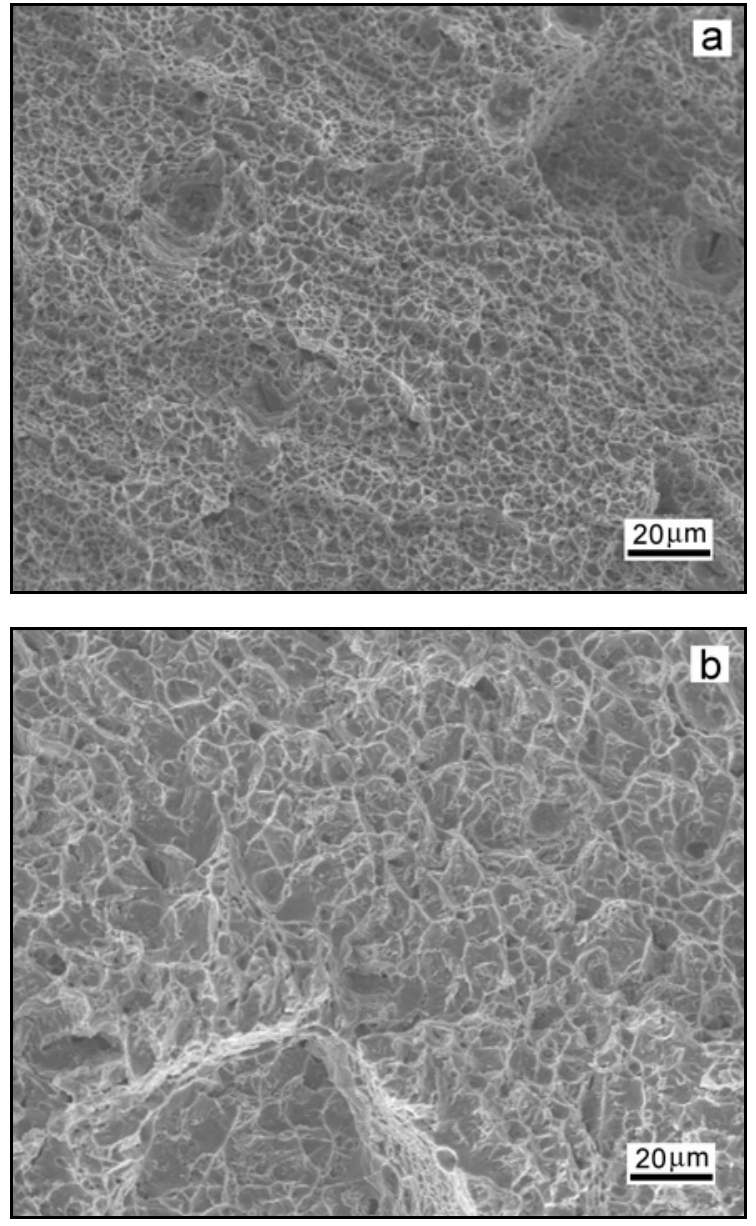

Fig. 10. SEM fractographs of individual $\mathrm{HAZ}$ regions of a T24/T92 weldment in PWHT state after the room-temperature tensile testing without hydrogen precharging: T24 HAZ (a) and T92 HAZ (b).

creased amount of quasi-cleavage fracture initiated on the large secondary phase particles and/or inclusions (see Fig. 11a). Similar fracture behaviour of HAZ regions was observed during tensile straining of low alloy steels weldments [51]. In contrast, the same conditions of thermal exposure resulted in significant changes of T92 HAZ fracture mode, manifested mainly by the transition from ductile dimple fracture in PWHT state (Fig. 10b) to the mixed fracture mode consisting mainly of transgranular quasi-cleavage and a small portion of intergranular decohesion (Fig. 11b).

The occurrence of some intergranular facets on the fracture surface of T92 HAZ can be correlated with intensive secondary phase precipitation during longterm thermal exposure including intermetallic Laves phase formation in the vicinity of intergranular $\mathrm{M}_{23} \mathrm{C}_{6}$ carbides and their coarsening (Fig. 8). The coarsening rate of Laves phase is faster than that of $\mathrm{M}_{23} \mathrm{C}_{6}$ carbides, and the finest MX particles seem to be thermally stable as their size and distribution do not un- 

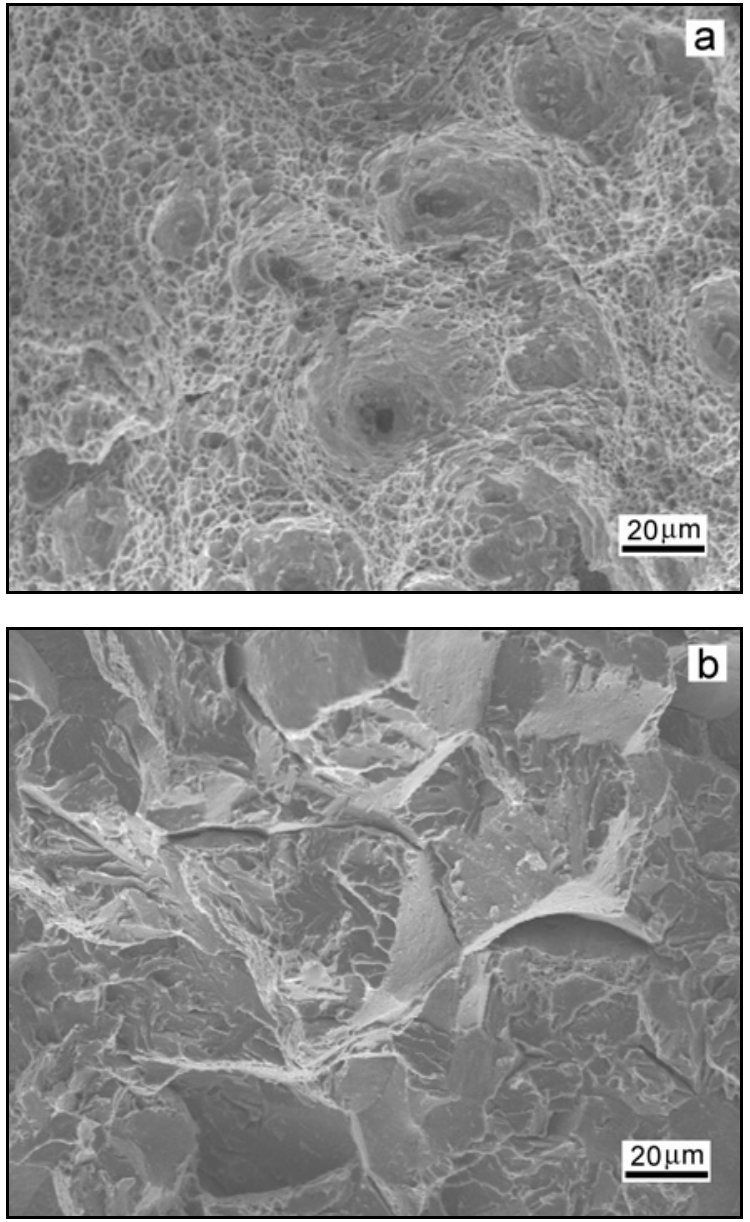

Fig. 11. SEM fractographs of individual HAZ regions of $\mathrm{T} 24 / \mathrm{T} 92$ weldment isothermally aged at $600^{\circ} \mathrm{C}$ for $5000 \mathrm{~h}$ and subsequently room-temperature tensile tested without hydrogen pre-charging: T24 HAZ (a) and T92 HAZ (b).

dergo any significant changes during the long-term ageing process $[23,24,40,41]$.

Figure 12 shows fracture surfaces of T24 HAZ and T92 HAZ regions of thermally exposed $\left(600^{\circ} \mathrm{C} / 5000 \mathrm{~h}\right)$ and hydrogen charged weldments after room-temperature notch tensile tests. Both these fractographs exhibit qualitatively similar fracture features including transgranular cleavage facets and intergranular dimple areas.

The differences in size and portion of individual fractographic characteristics in individual HAZ regions can be correlated with their different microstructures (Figs. 7, 8) and mechanical properties (Fig. 6). According to specific morphological terminology for hydrogen embrittlement fracture features, described e.g. in [52-54], the typical "fish-eyes" and "crows-feet" marks are clearly distinguishable on fracture surfaces of T24 HAZ and T92 HAZ, respectively. It can reasonably be assumed that the aged HAZ regions contain a higher concentration of hydrogen than base mate-
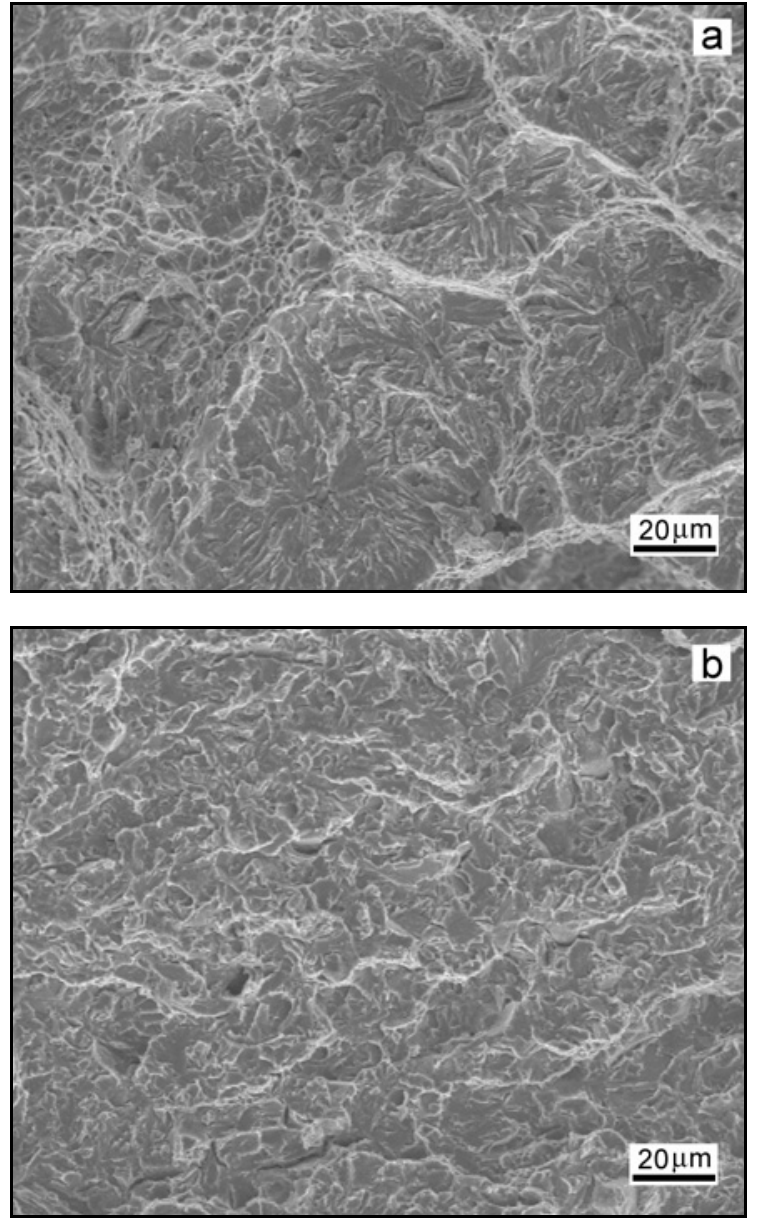

Fig. 12. SEM fractographs of individual HAZ regions of $\mathrm{T} 24 / \mathrm{T} 92$ weldment isothermally aged at $600^{\circ} \mathrm{C}$ for $5000 \mathrm{~h}$ and subsequently room-temperature tensile tested with hydrogen pre-charging: T24 HAZ (a) and T92 HAZ (b).

rials under the same cathodic charging conditions. The higher solubility of hydrogen in the aged HAZ regions of steels may be interpreted in terms of an increased capacity of hydrogen trapping sites, namely the carbide/matrix interfaces [47-50], caused by the higher volume fraction of carbides formed in microstructures with the higher initial level of transformation hardening after the welding process. However, the hydrogen is well-known to be distributed in steels heterogeneously. In the local area, such as crack tip, microvoids, grain boundaries, matrix/particles interfaces and inclusions, the hydrogen concentration is very high. As the hydrogen migrates via diffusion paths, it encounters hydrogen traps where it is arrested, which leads to the increase in hydrogen concentration of the local area [55, 56]. If it exceeds a critical value under certain stress conditions, the crack may initiate there. Thus, the coarse precipitates of secondary phase particles and/or inclusions may act like cracking nucleation sites in hydrogen pre-charged HAZ regions (see Fig. 13). 

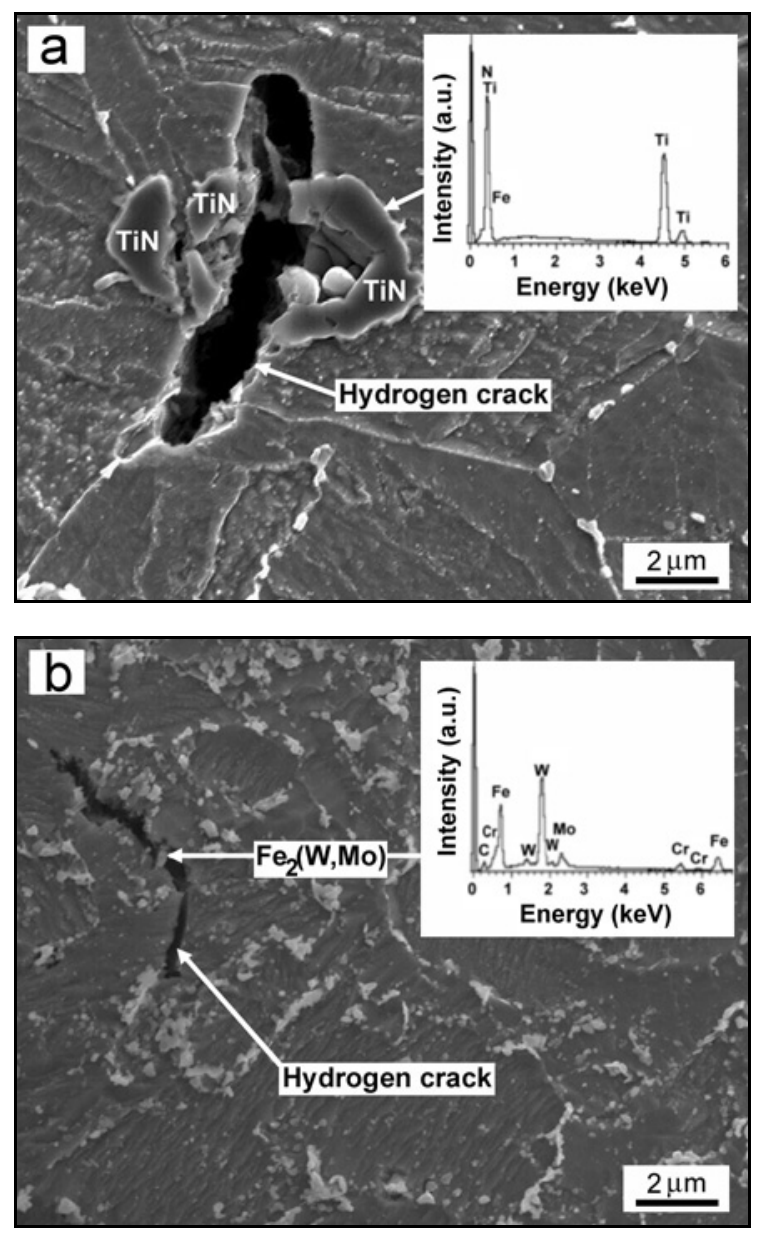

Fig. 13. The occurrence of cracks in hydrogen pre-charged and tensile tested HAZ microstructures of thermally aged T24/T92 weldment: T24 HAZ (a) and T92 HAZ (b).

Mutually differing morphological characteristics of hydrogen assisted cracks observed in strained tensile T24 and T92 HAZs regions of thermally exposed $\left(600^{\circ} \mathrm{C} / 5000 \mathrm{~h}\right) \mathrm{T} 24 / \mathrm{T} 92$ weldment can be directly related to their individual microstructural characteristics beneath their fracture surfaces. The observed microstructural and fracture features (Figs. 7, 8 and Figs. 10-12) in relation to the obtained mechanical properties of distinct HAZ regions (Fig. 6) indicated pronounced hydrogen embrittlement effects for both T24 HAZ and T92 HAZ of the weldment studied in the present investigation.

\section{Summary and conclusions}

Local mechanical properties and fracture behaviour of coarse-grained heat-affected zones of Ni-based transition weldments between T24 and T92 creep-resistant steels were investigated in relation to their microstructure evolution during ageing at $600^{\circ} \mathrm{C}$ and the application of hydrogen charging. The obtained results can be summarized in the following conclusions:

- Hardness measurements across the studied weldment showed the steep hardness gradients within its individual heat-affected zones with the hardness peaks located in over-heated coarse-grained regions due to the highest level of transformation hardening.

- Long-term isothermal ageing at $600^{\circ} \mathrm{C}$ of dissimilar T24/T92 weldment led to microstructural changes in its individual $\mathrm{HAZ}$ regions manifested by the coarsening of original Cr-rich carbides $\left(\mathrm{M}_{7} \mathrm{C}_{3}\right.$ and $\mathrm{M}_{23} \mathrm{C}_{6}$ ) with additional precipitation of Mo-rich carbides (mainly $\mathrm{M}_{6} \mathrm{C}$ ) and intermetallic $\mathrm{Fe}_{2}(\mathrm{~W}, \mathrm{Mo}$ ) Laves phase in T24 and T92 HAZs, respectively.

- Notch tensile strength $\left(R m_{\mathrm{V}}\right)$ values of both T24 and T92 HAZs without hydrogen charging exhibited initial increase after $1000 \mathrm{~h}$ of ageing at $600{ }^{\circ} \mathrm{C}$, followed by their gradual decrease with increasing ageing duration up to $5000 \mathrm{~h}$. This behaviour can be related to the additional precipitation of newly-formed secondary phases followed by their subsequent coarsening. In contrast, the values of reduction of area under the notch $\left(R A_{\mathrm{V}}\right)$ have experienced simple monotonous decreasing due to successive accumulation of thermal embrittlement effects with increasing ageing time.

- Hydrogen charging of T24/T92 welded joints in all heat-treated states (PWHT, $600{ }^{\circ} \mathrm{C} / 1000 \mathrm{~h}$, and $600{ }^{\circ} \mathrm{C} / 5000 \mathrm{~h}$ ) resulted in remarkable hardening effects on the notch tensile strength and gradual detrimental effects on the plasticity of both studied HAZ regions. However, the relative differences in $R A_{\mathrm{V}}$ values between the hydrogen free and hydrogen charged specimens are always lower for T92 HAZ, compared to T24 HAZ. This indicates the higher resistance of T92 HAZ against hydrogen embrittlement which can be attributed to its higher precipitate density and thus hydrogen-trapping capacity.

- Fracture behaviour of the both studied HAZ regions of a T24/T92 weldment in initial PWHT state without hydrogen pre-charging was characterized by ductile tearing with different dimple size and morphology related to their specific microstructural features. Subsequent effects of long-term ageing caused noticeable changes in both the HAZs fracture behaviour. The region of T24 HAZ still exhibited ductile dimples but also an increased amount of quasi-cleavage fracture initiated on the large precipitates and/or inclusions. In contrast, the T92 HAZ has experienced a transition from ductile dimple tearing in its initial PWHT state to the mixed fracture mode consisting of transgranular quasi-cleavage and a small portion of intergranular decohesion.

- After hydrogen pre-charging before tensile testing, the both HAZ regions of thermally exposed T24/T92 weldment showed specific signs of hydrogen embrittlement on their fracture surfaces including transgranular quasi-cleavage areas with "fish-eyes" 
and "crows-feet" marks for T24 and T92 HAZs, respectively. The differences in individual fractographic morphological features of the specific HAZ regions correlate with their microstructural and mechanical characteristics obtained in conditions of the present study.

\section{Acknowledgements}

This work was realized within the frame of the project Research Centre of Advanced Materials and Technologies for Recent and Future Applications "PROMATECH", ITMS project code: 26220220186 , which is supported by the Operational Program "Research and Development" financed through European Regional Development Fund and financially supported by the Slovak Scientific Grant Agency (VEGA) under the Grant No. 2/0151/16. The authors wish to thank Dr. Juraj Blach (retired from IMR SAS, Košice) for his helpful comments during the manuscript preparation and encouragement.

\section{References}

[1] Parker, J.: Int. J. Press. Vessels Pip., 114-115, 2014, p. 76. doi:10.1016/j.ijpvp.2012.11.004

[2] Shokouhmand, H., Ghadimi, B., Espanani, R.: Eng. Fail. Anal., 50, 2015, p. 20. doi:10.1016/i.engfailanal.2015.01.003

[3] Siegl, J., Haušild, P., Janča, A., Kopřiva, R., Kytka, M.: Key Eng. Mater., 606, 2014, p. 15. doi:10.4028/www.scientific.net/KEM.606.15

[4] Petzová, J., Březina, M., Kapusňák, M., Kupča, L.: In: Proceedings of ASME 2015 Pressure Vessels and Piping Conference. New York, ASME 2015, p. V01AT01A063. doi:10.1115/PVP2015-45539

[5] Laha, K., Chandravathi, K. S., Parameswaran, P., Goyal, S., Mathew, M. D.: Metall. Mater. Trans. A, 43, 2012, p. 1174. doi:10.1007/s11661-011-0957-8

[6] Fan, K., Wang, G. Z., Xuan, F. Z., Tu, S. T.: Eng. Fail. Anal., 59, 2016, p. 419. doi:10.1016/i.engfailanal.2015.11.005

[7] Stř́lková, L., Holešinský, J., Maslova, A., Kuboň, Z., Vodárek, V.: Mater. Sci. Forum, 782, 2014, p. 319. doi:10.4028/www.scientific.net/MSF.782.319

[8] Tabuchi, M., Hongo, H., Abe, F.: Metall. Mater. Trans. A,45, 2014, p. 5068. doi:10.1007/s11661-014-2471-2

[9] Bendick, W., Gabrel, J., Hahn, B., Vandenberghe, B.: Int. J. Press. Vessels Pip., 84, 2007, p. 13. doi:10.1016/j.ijpvp.2006.09.002

[10] Golanski, G., Jasak, J., Slania, J.: Kovove Mater., 52, 2014, p. 99. doi:10.4149/km_2014_2_99

[11] Mohyla, P., Foldyna, V.: Mater. Sci. Eng. A, 510-511, 2009, p. 234. doi:10.1016/i.msea.2008.05.056

[12] Aghajani, A., Somsen, Ch., Pesicka, J., Bendick, W., Hahn, B., Eggeler, G.: Mater. Sci. Eng. A,510-511, 2009, p. 130. doi:10.1016/j.msea.2008.08.049

[13] Vodárek, V., Rožnovská, G., Holešinský, J., Maslova, A., Kuboň, Z.: Mater. Sci. Forum, 782, 2014, p. 143. doi:10.4028/www.scientific.net/MSF.782.143
[14] Mojžiš, M., Domovcová, L., Weiss, M., Fujda, M., Parilák, L.: Mater. Sci. Forum, 782, 2014, p. 133. doi:10.4028/www.scientific.net/MSF.782.133

[15] Zieliński, A., Dobrzański, J.: Arch. Mater. Sci. Eng., 58, 2012, p. 5.

[16] Zifčák, P., Brziak, P., Balog, M., Bošanský, J., Srnka, M.: Acta Metall. Slovaca, 14, 2008, p. 195.

[17] Maruyama, K., Sawada, K., Koike, J.-I.: ISIJ International, 41, 2001, p. 641. doi:10.2355/isijinternational.41.641

[18] Ennis, P. J., Czyrska-Filemonowicz, A.: Sādhanā, 28, 2003, p. 709. doi:10.1007/BF02706455

[19] Meng, D., Lu, F., Cui, H., Ding, Y., Tang, X., Huo, X.: J. Mater. Res., 30, 2015, p. 197. doi:10.1557/imr.2014.366

[20] Cieśla, M., Junak, G.: Arch. Metall. Mat., 60, 2015, p. 1853. doi:10.1515/amm-2015-0316

[21] Falat, L., Kepič, J., Ciripová, L., Sevc, P., Dlouhý, I.: J. Mater. Res., 31, 2016, p. 1532. doi:10.1557/jmr.2016.134

[22] Zielinski, A., Golanski, G., Sroka, M.: Kovove Mater., 54, 2016, p. 61 . doi:10.4149/km_2016_1_61

[23] Zhao, L., Jing, H., Xu, L., Han, Y., Xiu, J.: Eng. Fail. Anal., 19, 2012, p. 22. doi:10.1016/j.engfailanal.2011.09.003

[24] Kasl, J., Jandová, D., Kanta, V.: Weld. World, 53, 2009, p. 155.

[25] Sopoušek, J., Foret, R.: Sci. Techn. Weld Joining, 13, 2008, p. 17. doi:10.1179/174329307X213918

[26] Novotný, J., Honzíková, J., Pilous, V., Stránský, K.: Manuf. Technol., 15, 2015, p. 1028.

[27] Anand, R., Sudha, C., Karthikeyan, T., Terrance, A. L. E., Saroja, S., Vijayalakshmi, M.: J. Mater. Sci., 44, 2009, p. 257. doi:10.1007/s10853-008-3052-9

[28] Dayal, R. K., Parvathavarthini, N.: Sādhanā, 28, 2003, p. 431. doi:10.1007/BF02706442

[29] Manimozhi, S., Suresh, S., Muthupandi, V.: Int. J. Manuf. Technol., 51, 2010, p. 217. doi:10.1007/s00170-010-2611-9

[30] Lynch, S.: Corros. Rev., 30, 2012, p. 105. doi:10.1515/corrrev-2012-0502

[31] Liu, Q., Atrens, A.: Corros. Rev., 31, 2013, p. 85. doi:10.1515/corrrev-2013-0023

[32] Magudeeswaran, G., Balasubramanian, V., Madhusudha Reddy, G.: Int. J. Hydrogen Energy, 33, 2008, p. 1897. doi:10.1016/j.ijhydene.2008.01.035

[33] Sozańska, M., Sojka, J., Betáková, P., Dagbert, C., Hyspecká, L., Galland, J., Tvrdý, M.: Mater. Charact., 46, 2001, p. 239. doi:10.1016/S1044-5803(01)00130-9

[34] Nagao, A., Smith, C. D., Dadfarnia, M., Sofronis, P., Robertson, I. M.: Acta Mater., 60, 2012, p. 5182. doi:10.1016/i.actamat.2012.06.040

[35] Blach, J., Falat, L., Ševc, P.: Eng. Fail. Anal., 18, 2011, p. 485. doi:10.1016/j.engfailanal.2010.09.043

[36] Blach, J., Falat, L.: High Temp. Mater. Proc., 33, 2014, p. 329. doi:10.1515/htmp-2013-0053

[37] www.thermocalc.se

[38] Kroupa, A., Havránková, J., Coufalová, M., Svoboda, M., Vreštál, J.: J. Phase Equil., 22, 2001, p. 312. doi:10.1361/105497101770338824

[39] Falat, L., Výrostková, A., Svoboda, M., Milkovič, O.: Kovove Mater., 49, 2011, p. 417. doi:10.4149/km_2011_6_417 
[40] Falat, L., Čiripová, L., Kepič, J., Buršík, J., Podstranská, I.: Eng. Fail. Anal., 40, 2014, p. 141. doi:10.1016/j.engfailanal.2014.02.018

[41] Falat, L., Svoboda, M., Výrostková, A., Petryshynets, I., Sopko, M.: Mater. Charact., 72, 2012, p. 15. doi:10.1016/j.matchar.2012.06.014

[42] Zhu, M.-L., Wang, D.-Q., Xuan, F.-Z.: Mater. Charact., 87,2014 , p. 45. doi:10.1016/i.matchar.2013.10.026

[43] Lomozik, M., Zeman, M., Jachym, R.: Kovove Mater., 50, 2012, p. 285. doi:10.4149/km_2012_4_285

[44] Horník, J., Zuna, P., Málek, J., Jetmar, T., Kasl, J., Matějová, M., Jandoš, F.: Key Eng. Mater., 647, 2015, p. 38. doi:10.4028/www.scientific.net/KEM.647.38

[45] Maussner, G., Scharf, L., Langer, R., Gurovich, B.: Nucl. Eng. Des., 193, 1999, p. 359. doi:10.1016/S0029-5493(99)00192-2

[46] Capelle, J., Gilgert, J., Dmytrakh, I., Pluvinage, G.: Eng. Fract. Mech., 78, 2011, p. 364. doi:10.1016/j.engfracmech.2010.10.007

[47] Shibata, A., Murata, T., Takahashi, H., Matsuoka, T., Tsuji, N.: Metall. Mater. Trans. A, 46, 2015, p. 5685. $\underline{\text { doi:10.1007/s11661-015-3176-x }}$
[48] Bezecný, J. Vavrík, R., Dubec, A.: Vlákna a Textil/Fibres and Textiles, 21, 2014, p. 14.

[49] Begić Hadžipašić, A., Malina, J., Nižník, Š.: Kovove Mater., 50, 2012, p. 345. doi:10.4149/km_2012_5_345

[50] Rosenberg, G., Sinaiová, I., Hvizdoš, P., Juhar, L.: Metall. Mater. Trans. A, 46, 2015, p. 4755. doi:10.1007/s11661-015-3074-2

[51] Kim, J. H., Oh, Y. J., Hwang, I. S., Kim, D. J., Kim, J. T.: J. Nucl. Mater., 299, 2001, p. 132. doi:10.1016/S0022-3115(01)00688-2

[52] Rhode, M., Steger, J., Boellinghaus, T., Kannengiesser, T.: Weld. World, 60, 2016, p. 201. doi:10.1007/s40194-015-0285-5

[53] Sojka, J., Vodárek, V., Schindler, I., Ly, C., Jérôme, M., Váňová, P., Ruscassier, N., Wenglorzová, A.: Corr. Sci., 53, 2011, p. 2575. doi:10.1016/j.corsci.2011.04.015

[54] Bezecný, J., Dubec, A., Vavrík, R.: Hutnické Listy, 66, 2013, p. 14.

[55] Lynch, S. P.: In: Proceedings of CORROSION 2007. Houston, NACE International 2007, NACE-07493.

[56] Martin, M. L., Fenske, J. A., Liu, G. S., Sofronis, P., Robertson, I. M.: Acta Mater., 59, 2011, p. 1601. doi:10.1016/j.actamat.2010.11.024 